\title{
Erythrocyte Morphology and Haemoglobin Types of Neonatal Roan Antelopes (Hippotragus equinus) with Hypochromic Poikilocytic Anaemia
}

\author{
S.D.C. Parsons, B.L. Penzhorn, F. Reyers, J.C.A. Steyl and P.J. Becker
}

\section{Summary}

Neonatal, poikilocytic anaemia in some members of the Hippotragini has previously been documented but not fully investigated. This study was undertaken to describe the erythrocyte morphology of roan antelopes (Hippotragus equinus) during the first 4 weeks after birth and to identify aspects of haemoglobin $(\mathrm{Hb})$ production that might be implicated in this syndrome. Twenty-nine roan antelope calves were sampled on, or close to, 1, 7, 14 and 28 days after birth. Erythrocyte morphology was characterized, and microhaematocrit values and $\mathrm{Hb}$ parameters determined, for each sampling occasion. Findings indicated a significant change in erythrocyte morphology during the neonatal period and two haemoglobin types, fetal and adult, were identified. The perinatal onset of adult $\mathrm{Hb}$ synthesis was delayed relative to the termination of fetal $\mathrm{Hb}$ production, resulting in the observed anaemia. Haemoglobin concentration and erythrocyte morphology were significantly correlated. These findings suggest an intimate relationship between $\mathrm{Hb}$ synthesis and the observed poikilocytosis. An imbalance in the synthesis of the $\alpha$ - and $\beta$-globin chains of $\mathrm{Hb}$ (a thalassaemia) may prove to be the underlying pathophysiology of this syndrome.

\section{Article Outline}

1. Introduction

2. Materials and Methods

2.1. Animals

2.2. Haemoglobin Analysis

2.3. Haematology

2.4. Erythrocyte Morphology

2.5. Statistical Analysis

3. Results

3.1. Haemoglobin Analysis by HPLC

3.2. Haemoglobin Analysis by Electrophoresis

3.3. Microhaematocrit and Haemoglobin Parameters

3.4. Erythrocyte Morphology

3.5. Regression of Erythrocyte Types on Hb Parameters

4. Discussion

Acknowledgements

References 


\section{Introduction}

Neonatal anaemia, often in association with poikilocytosis, has been described in numerous ruminant species and is especially pronounced amongst members of the Hippotragini (Bush et al., 1976; Hawkey and Hart, 1984; Hawkey and Dennett, 1989). Goats (Capra hircus) also display a neonatal poikilocytic anaemia (Holman and Drew, 1964). In that species, poikilocytosis occurring in adult-onset anaemia has been associated with the production of haemoglobin C ( $\mathrm{HbC}$ ) (Jain et al., 1980), which is also produced during the neonatal period (Huisman et al., 1969). Steyl et al. (2003) reported on this syndrome in the roan antelope (Hippotragus equinus), speculating on the relationship between anaemia and the high mortality from theileriosis in neonatal animals of this valuable species.

In this study, the hypochromic, poikilocytic anaemia of neonatal roan antelopes was investigated. Poikilocytosis is associated with erythrocyte membrane abnormalities, while hypochromasia is an indication of impaired haemoglobin synthesis (Bell, 1998). The aims of the study were (1) to characterize, by electrophoresis and chromatography, the occurrence of haemoglobin variants during the neonatal period, (2) to describe the changes in morphology of erythrocytes during this period, and (3) to seek a possible association between haemoglobin synthesis and the observed poikilocytosis.

\section{Materials and Methods}

\subsection{Animals}

Animals used in this study comprised the first 29 calves born to a privately owned captive population of West African roan antelope on Mauricedale Game Ranch, near Malelane, Mpumalanga Province, South Africa ( $\left.25^{\circ} 30^{\prime \prime} 00^{\prime \prime S} 31^{\circ} 30^{\prime} 00^{\prime \prime} \mathrm{E}\right)$. Calves were hand-reared from the age of 1 day and fed a cow milk formula at approximately $10 \%$ body weight per day. During this investigation, a rotavirus outbreak in the calves resulted in treatment of those showing haemorrhagic diarrhoea with a potentiated sulphonamide antibiotic (Trivetrin; Schering-Plough Animal Health, Johannesburg, South Africa) for 39 days $(15 \mathrm{mg} / \mathrm{kg}$ daily). These animals displayed significant increases in microhaematocrit $(\mathrm{Hct})$ and haemoglobin $(\mathrm{Hb})$ concentration during the treatment periods, suggesting that parameters measured in this study were not significantly affected by this episode. When possible, blood (4 ml) was collected from each animal, on ca 1, 7, 14 and 28 days after birth, and transferred to a tube containing potassium ethylenediamine-tetraacetate (EDTA) (Vacutainer; Becton Dickinson Vacutainer Systems, Preanalytical Solutions, Plymouth, England). 


\subsection{Haemoglobin Analysis}

Haemolysates were prepared within $36 \mathrm{~h}$ of sampling (Beckman Paragon Hemolyzing Reagent; Beckman Coulter, Inc., Fullerton, CA, USA) and stored at $-20{ }^{\circ} \mathrm{C}$. Samples were analysed for $\mathrm{Hb}$ variants with a commercial Cation Exchange High Performance Liquid Chromatography (CE-HPLC) system (VARIANT ${ }^{\mathrm{TM}}$ Hemoglobin Testing System and VARIANT ${ }^{\text {TM }}$ Hemoglobinopathy Program; Bio-Rad Laboratories, Hercules, CA, USA). This system was capable of separating fetal, neonatal and adult haemoglobins of goats (unpublished data). Analysis was performed according to the manufacturer's instructions except for initial sample preparation. As a result of the low $\mathrm{Hb}$ concentrations of the samples tested, for each sample $1.0 \mathrm{ml}$ of haemolysis reagent supplied with the system was added to $25 \mu$ of thawed haemolysate rather than to $20 \mu \mathrm{l}$ (as used for human neonatal samples).

Electrophoresis of haemolysates was performed with a commercial electrophoresis system (Sebia MG 300 electrophoresis system and Sebia Hydragel Hemoglobin K (20) agarose gel kits; Sebia, Issy-les-Moulineaux, France). Densitometry of stained electrophoregrams was performed with a yellow filter (Sebia DVSE densitometer; Sebia).

\subsection{Haematology}

Microhaematocrit was determined manually following microcentrifugation (Hema-C; Jouan, Winchester, VA, USA). Haemoglobin concentrations were determined by automated spectrophotometry (Cell-dyne 3500; Abbott Laboratories, Abbott Park, IL, USA). Absolute concentrations of $\mathrm{Hb}$ fractions were calculated by multiplying relative values as determined by chromatography by total $\mathrm{Hb}$ concentration. For each sampling occasion, mean cell $\mathrm{Hb}$ concentrations were determined by dividing $\mathrm{Hb}$ concentration by the microhaematocrit value.

\subsection{Erythrocyte Morphology}

Immediately after sampling, 3 blood smears were made by hand and stained as follows: one with Romanowsky stain (Rapidiff; Clinical Sciences Diagnostics, Johannesburg, South Africa), one with New Methylene Blue stain (Reticulocyte Stain; Clinical Sciences Diagnostics), and one with Prussian Blue stain as described by Swirsky and Bain (2001). From each smear, digital photomicrographs were taken (Olympus Camedia C-3040 ZOOM; Olympus Corporation, Tokyo, Japan) of 10 fields from the front part of the smear (excluding the feathered edge), in which cells had maintained a biconcave morphology and as few cells as possible were touching one another. Five digital photomicrographs from each smear were examined. Erythrocytes were categorized according to morphology (Romanowsky-stained smears) and inclusions present (Table 1) and the number of each cell type was recorded. Cells not completely included by the borders of the image, those deformed by neighbouring cells or smear artefacts and those categorized as echinocytes were excluded from the study. Mean cell surface area (MCA) was quantified with ImageJ, an image processing and analysis programme in the public domain, obtained from the National Institutes of Health, USA. Anisocytosis, a measure of 
the variation in erythrocyte surface area, was quantified as the coefficient of variation of the MCA.

Table 1.

Terms describing erythrocyte types based on morphology and inclusions present (compiled from Bessis, 1977 and Jain, 1986)

\begin{tabular}{|c|c|}
\hline Cell type & Morphological description \\
\hline Acanthocyte & $\begin{array}{l}\text { A spheroidal cell with } 3-12 \text { often club-like spicules of uneven length, } \\
\text { irregularly distributed over the cell surface }\end{array}$ \\
\hline Elliptocyte & $\begin{array}{l}\text { An oval-shaped cell ranging from that slightly more oval than the } \\
\text { discocyte to almost rod-shaped }\end{array}$ \\
\hline Keratocyte & $\begin{array}{l}\text { A cell displaying one or more notches. Horn-like projections extend from } \\
\text { one or more of the borders of the notch }\end{array}$ \\
\hline Schizocyte & $\begin{array}{l}\text { A fragment of a cell following damage to it. These fragments may } \\
\text { resemble portions of the original cell or occur as bizarre forms }\end{array}$ \\
\hline Dacryocyte & A tear-shaped cell with an extended tail \\
\hline Echinocyte & A cell with 10-30 spicules distributed regularly over the surface \\
\hline Spherocyte & $\begin{array}{l}\text { A densely staining spherical, globular or acanthocytic cell with no central } \\
\text { pallor }\end{array}$ \\
\hline Siderocyte & $\begin{array}{l}\text { An erythocyte containing increased numbers of ferritin granules which } \\
\text { stain blue with Prussian Blue stain }\end{array}$ \\
\hline Reticulocyte & $\begin{array}{l}\text { A cell displaying two or more well-defined blue-staining aggregates of } \\
\text { irregular shape and distribution when supra-vitally stained with New } \\
\text { Methylene Blue stain }\end{array}$ \\
\hline $\begin{array}{l}\text { Howell-Jolly } \\
\text { body cell }\end{array}$ & $\begin{array}{l}\text { An erythocyte containing a Howell-Jolly body: a small, dark, round } \\
\text { inclusion, often occurring eccentrically }\end{array}$ \\
\hline
\end{tabular}

\subsection{Statistical Analysis}

This was performed with STATA, Release 8 (StataCorp LP, College Station, TX, USA). To describe changes in erythrocyte and $\mathrm{Hb}$ parameters within individuals over time, cross-sectional time-series regression models were employed to regress each erythrocyte and $\mathrm{Hb}$ parameter on calf age. To investigate relationships between $\mathrm{Hb}$ synthesis and 
erythrocyte morphology, each erythrocyte parameter was regressed on each $\mathrm{Hb}$ parameter as above.

\section{Results}

\subsection{Haemoglobin Analysis by HPLC}

Chromatograms derived from the CE-HPLC of neonatal roan antelope haemoglobins revealed five distinct peaks (Fig. 1). The second peak occasionally separated into two peaks of equal area (Fig. 1a, c); however, this division was interpreted as spurious. The first three peaks occurred consistently in ratios of approximately 1:4:5 and decreased in relative size with increasing age of the calves. These were identified as fetal haemoglobin variants. The fourth and fifth peaks occurred consistently in a ratio of approximately $1: 3.5$, increased in relative size with calf age, and were identified as adult haemoglobin variants. 

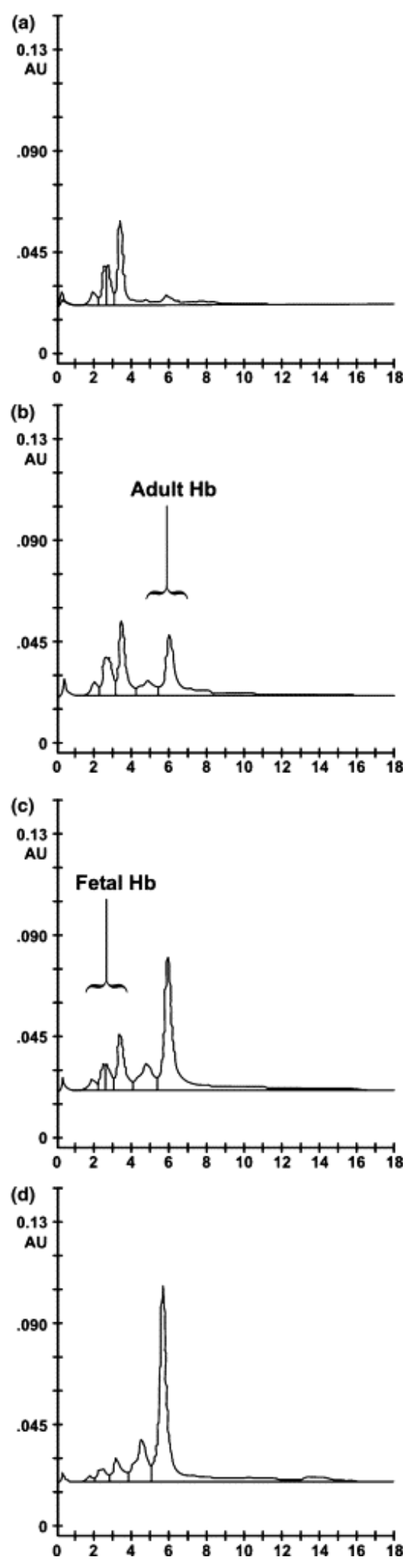

Fig. 1. Bio-Rad VARIANT ${ }^{\mathrm{TM}}$ printouts of chromatograms of roan antelope haemoglobins (calf 308) at (a) 1, (b) 8, (c) 15 and (d) 29 days after birth ( $x$-axis, time (minutes); $y$-axis, absorbance (arbitrary units)). 


\subsection{Haemoglobin Analysis by Electrophoresis}

Electrophoregrams of neonatal roan antelope haemoglobins revealed two distinct bands (Fig. 2). The faster band decreased in relative size with increasing age of the calves and was identified as fetal haemoglobin. The slower band increased in relative size with increasing calf age and was identified as adult haemoglobin.

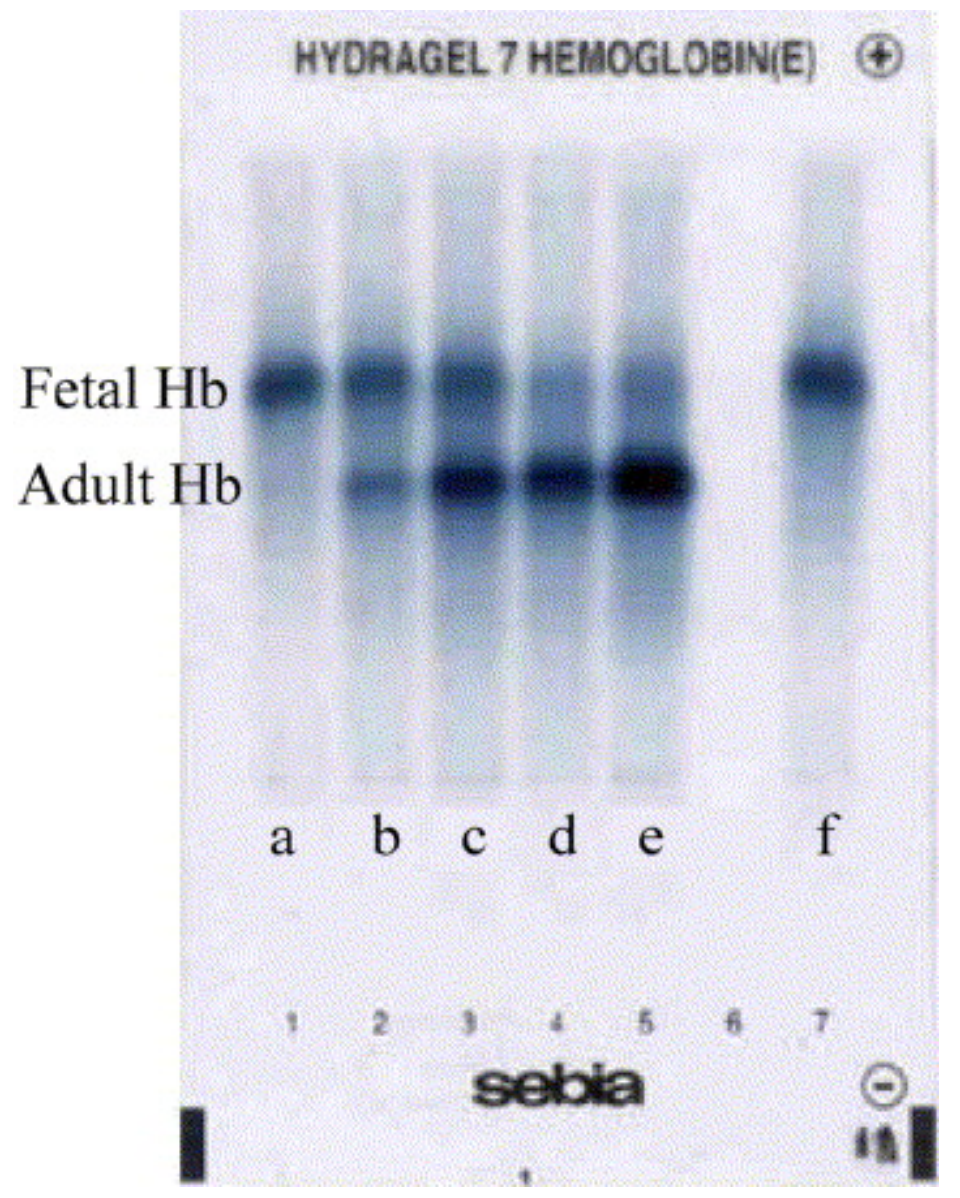

Fig. 2. Electrophoregrams of roan antelope haemoglobins (calf 308) at (a) 1, (b) 8, (c) 15, (d) 21, and (e) 29 days after birth; and (f) calf 325 haemoglobins at 1 day after birth.

\subsection{Microhaematocrit and Haemoglobin Parameters}

During the first 4 weeks after birth, roan antelope calves showed a significant increase in haematocrit, total $\mathrm{Hb}$ concentration, mean cell $\mathrm{Hb}$ concentration, adult $\mathrm{Hb}$ concentration and mean cell adult $\mathrm{Hb}$ concentration. Concurrently, a significant decrease in fetal $\mathrm{Hb}$ concentration and mean cell fetal Hb concentration occurred (Table 2, Fig. 3). 
Table 2 .

Changes in microhaematocrit and haemoglobin parameters of roan antelope calves during the first 4 weeks after birth

\begin{tabular}{|c|c|c|c|c|c|c|c|}
\hline \multirow[t]{2}{*}{ Parameter } & \multicolumn{4}{|c|}{ Results (mean \pm SD) } & \multicolumn{3}{|c|}{ Regression on calf age } \\
\hline & Day 1 & Day 7 & Day 14 & Day 28 & Summary & $\boldsymbol{P}$ & $r^{2}$ \\
\hline & $(n=29)$ & $(n=23)$ & $(n=18)$ & $(n=15)$ & & & \\
\hline $\begin{array}{l}\text { Microhae- } \\
\text { matocrit (\%) }\end{array}$ & $21.0 \pm 3.2$ & $26.6 \pm 3.1$ & $29.3 \pm 3.5$ & $33.0 \pm 3.1$ & $y=20.0+0.44(d)$ & $*$ & 0.6 \\
\hline Total Hb (g/dl) & $5.9 \pm 1.0$ & $7.4 \pm 1.1$ & $8.3 \pm 1.2$ & $10.2 \pm 1.3$ & $y=5.9+0.16(d)$ & $*$ & 0.65 \\
\hline \multirow[t]{2}{*}{$\begin{array}{l}\text { Mean cell } \mathrm{Hb} \\
(\mathrm{g} / \mathrm{dl})\end{array}$} & $27.9 \pm 2.5$ & $27.7 \pm 1.5$ & $28.6 \pm 1.8$ & $30.9 \pm 1.5$ & $y=27.4+0.11(\mathrm{~d})$ & $*$ & 0.24 \\
\hline & $(n=17)$ & $(n=22)$ & $(n=13)$ & $(n=14)$ & & & \\
\hline Total HbF (g/dl) & $4.8 \pm 0.9$ & $4.3 \pm 1.2$ & $3.4 \pm 0.9$ & $1.8 \pm 0.5$ & $y=4.8-0.11(d)$ & $*$ & 0.59 \\
\hline $\begin{array}{l}\text { Mean cell } \mathrm{HbF} \\
(\mathrm{g} / \mathrm{dl})\end{array}$ & $22.1 \pm 2.2$ & $15.9 \pm 2.5$ & $11.3 \pm 3.2$ & $5.6 \pm 1.9$ & $y=20.8-0.57(d)$ & $*$ & 0.78 \\
\hline Total HbA (g/dl) & $1.2 \pm 0.4$ & $3.1 \pm 0.8$ & $5.2 \pm 1.4$ & $8.5 \pm 1.8$ & $y=1.2+0.26(d)$ & $*$ & 0.84 \\
\hline $\begin{array}{l}\text { Mean cell } \mathrm{HbA} \\
(\mathrm{g} / \mathrm{dl})\end{array}$ & $5.5 \pm 1.6$ & $11.8 \pm 2.8$ & $17.4 \pm 3.9$ & $25.4 \pm 3.3$ & $y=6.3+0.7(\mathrm{~d})$ & $*$ & 0.84 \\
\hline
\end{tabular}

$\mathrm{Hb}, \mathrm{Hb}$ concentration; $\mathrm{HbA}$, adult $\mathrm{Hb}$ concentration; $\mathrm{HbF}$, fetal $\mathrm{Hb}$ concentration; $\mathrm{d}$, age in days; $*=P<0.01$. 


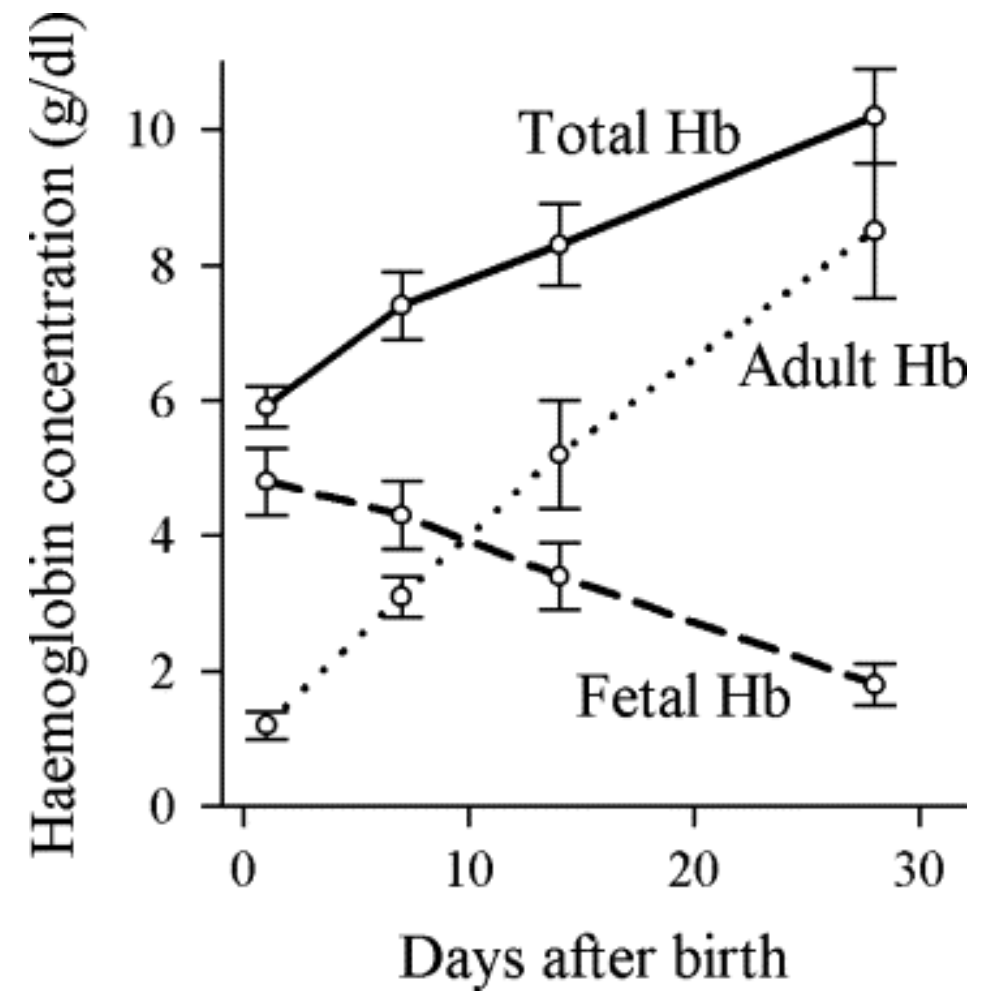

Fig. 3. Neonatal $\mathrm{Hb}$ switching pattern of the roan antelope. Mean $\mathrm{Hb}$ concentrations $(\mathrm{O})$ and $95 \%$ confidence limits ( $(T)$ on days $1,7,14$ and 28 after birth.

\subsection{Erythrocyte Morphology}

Blood smears made from roan antelope calves during the first 4 weeks after birth showed a predictable change in composition with regard to erythrocyte morphology (Fig. 4, Table $3)$. During this time there was a significant decrease in the number of elliptocytes, schizocytes, keratocytes and dacryocytes and a significant increase in that of acanthocytes and spherocytes. A peak in reticulocytosis occurred 7 days after birth, and in cells containing Howell-Jolly bodies, 14 days after birth, with MCA and anisocytosis peaking in conjunction with reticulocytosis. 

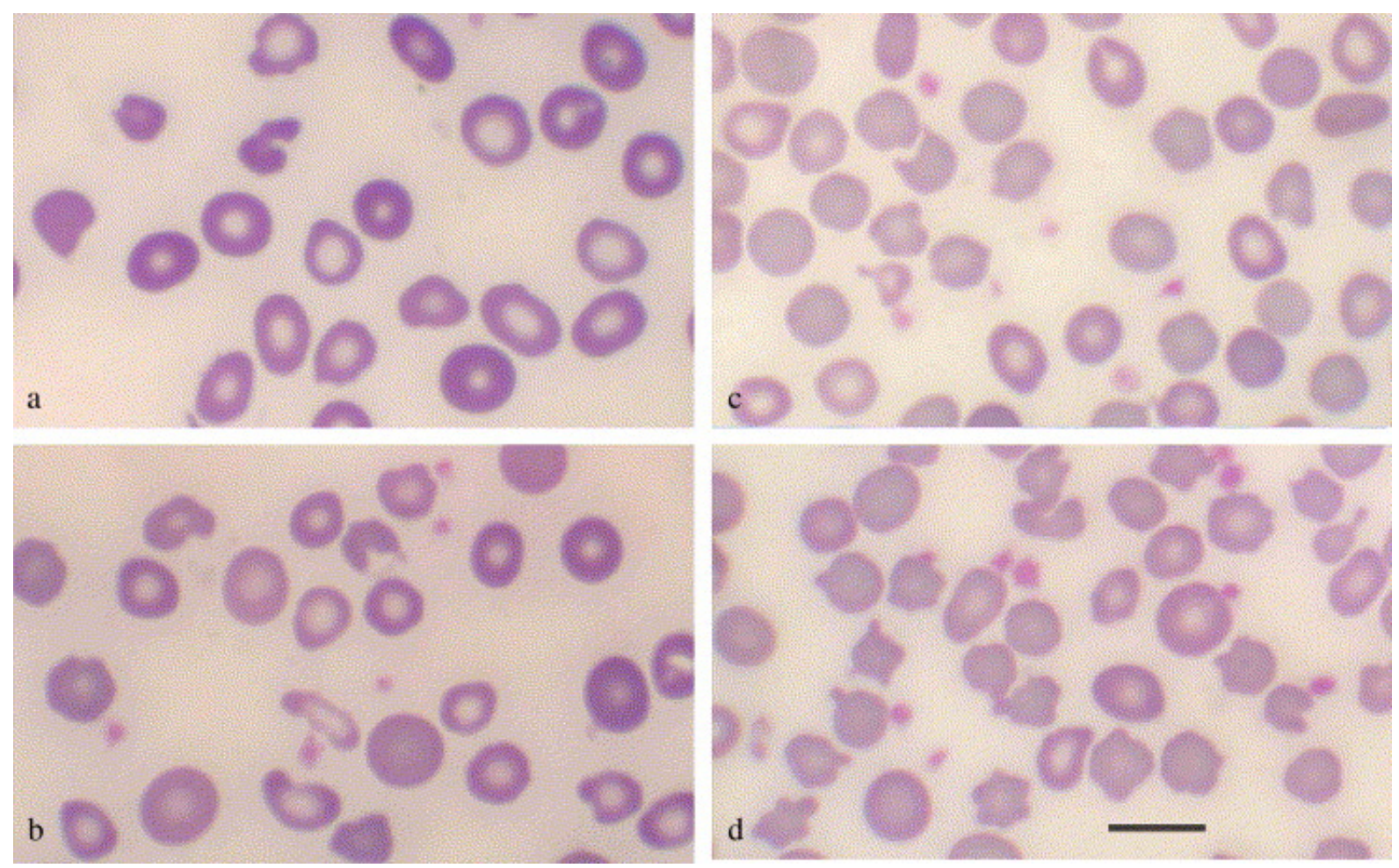

Fig. 4a-d. Erythrocytes from blood smears made from a roan antelope (calf 308) at (a) 1, (b) 8, (c) 15 and (d) 29 days after birth. Romanowsky stain. Bar, $20 \mu \mathrm{m}$.

Table 3.

Mean cell area, anisocytosis and the percentages of erythrocyte types in blood smears from neonatal roan antelopes

\begin{tabular}{|c|c|c|c|c|c|c|c|}
\hline \multirow[t]{2}{*}{ Parameter } & \multicolumn{4}{|c|}{ Results (mean \pm SD) } & \multicolumn{3}{|c|}{ Regression on calf age } \\
\hline & Day 1 & Day 7 & Day 14 & Day 28 & Summary & $P$ & $r^{2}$ \\
\hline & $(n=22)$ & $(n=20)$ & $(n=16)$ & $(n=15)$ & & & \\
\hline $\begin{array}{l}\text { Mean cell area } \\
\left(\mu \mathrm{m}^{2}\right)\end{array}$ & $75.5 \pm 3.8$ & $78.8 \pm 5.36$ & $73.5 \pm 4.5$ & $68.8 \pm 4.0$ & $y=77.8-0.31(\mathrm{~d})$ & $*$ & 0.7 \\
\hline Anisocytosis (\%) & $22.4 \pm 2.4$ & $27.1 \pm 7.0$ & $24.8 \pm 4.6$ & $24 \pm 3.7$ & $\cdots$ & n.s & $\cdots$ \\
\hline $\begin{array}{l}\text { Elliptocytosis } \\
(\%)\end{array}$ & $71.7 \pm 6.9$ & $61.3 \pm 14.1$ & $45.9 \pm 12.1$ & $38.7 \pm 16.9$ & $y=68.3-1.06(\mathrm{~d})$ & $*$ & 0.48 \\
\hline & & & & & & & \\
\hline
\end{tabular}




\begin{tabular}{|c|c|c|c|c|c|c|c|}
\hline \multirow[t]{2}{*}{ Parameter } & \multicolumn{4}{|c|}{ Results (mean \pm SD) } & \multicolumn{3}{|c|}{ Regression on calf age } \\
\hline & Day 1 & Day 7 & Day 14 & Day 28 & Summary & $\boldsymbol{P}$ & $r^{2}$ \\
\hline $\begin{array}{l}\text { Acanthocytosis } \\
(\%)\end{array}$ & $6.6 \pm 3.9$ & $3.1 \pm 3.5$ & $12.6 \pm 8.3$ & $28.1 \pm 13.1$ & $y=1.9+0.86(d)$ & $*$ & 0.52 \\
\hline $\begin{array}{l}\text { Schizocytosis } \\
(\%)\end{array}$ & $6.7 \pm 3.3$ & $4.3 \pm 2.4$ & $4.4 \pm 3.5$ & $1.7 \pm 1.3$ & $y=6.5-0.18(d)$ & $*$ & 0.26 \\
\hline $\begin{array}{l}\text { Keratocytosis } \\
(\%)\end{array}$ & $1.1 \pm 0.9$ & $0.7 \pm 1.0$ & $0.8 \pm 0.5$ & $0.3 \pm 0.6$ & $y=1.2-0.03(d)$ & $*$ & 0.1 \\
\hline $\begin{array}{l}\text { Dacryocytosis } \\
(\%)\end{array}$ & $0.5 \pm 0.6$ & $0.3 \pm 0.6$ & $0.5 \pm 0.7$ & 0 & $y=0.5-0.02(d)$ & $*$ & 0.07 \\
\hline \multirow[t]{2}{*}{$\begin{array}{l}\text { Spherocytosis } \\
(\%)\end{array}$} & $18.3 \pm 12.4$ & $28.5 \pm 13.1$ & $39.8 \pm 19.0$ & $70.1 \pm 17.4$ & $y=15.3+1.91(d)$ & $*$ & 0.61 \\
\hline & $(n=22)$ & $(n=20)$ & $(n=16)$ & $(n=14)$ & & & \\
\hline $\begin{array}{l}\text { Reticulocytosis } \\
(\%)\end{array}$ & $0.4 \pm 0.3$ & $0.8 \pm 1.4$ & $0.2 \pm 0.3$ & $0.2 \pm 0.3$ & $\ldots$ & n.s & $\ldots$ \\
\hline \multirow{2}{*}{$\begin{array}{l}\text { Cells containing } \\
\text { Howell-Jolly } \\
\text { bodies }(\%)\end{array}$} & $0.1 \pm 0.2$ & $0.2 \pm 0.2$ & $0.2 \pm 0.2$ & $0.1 \pm 0.2$ & $\ldots$ & n.s & $\ldots$ \\
\hline & $(n=19)$ & $(n=19)$ & $(n=16)$ & $(n=15)$ & & & \\
\hline $\begin{array}{l}\text { Siderocytosis } \\
(\%)\end{array}$ & $0.1 \pm 0.1$ & $0.1 \pm 0.2$ & $0.1 \pm 0.1$ & $0.1 \pm 0.1$ & $\ldots$ & n.s & $\ldots$ \\
\hline
\end{tabular}

d, age in days; $*=P<0.01 ;$ n.s., not significant; ..., no entry.

\subsection{Regression of Erythrocyte Types on Hb Parameters}

A significant increase in acanthocytosis and a decrease in elliptocytosis occurred with increasing adult $\mathrm{Hb}$ concentration. In addition, a significant increase in spherocytosis and decrease in schizocytosis occurred with increasing total $\mathrm{Hb}$ concentration (Table 4 ). 
Table 4.

Regression of erythrocyte types on $\mathrm{Hb}$ parameters of neonatal roan antelopes

\begin{tabular}{|l|l|l|}
\hline Parameter (\%) & \multicolumn{2}{|c|}{ Regression analysis } \\
\hline & Summary & $r^{2}$ \\
\hline Elliptocytosis & $y=100-5.7(\mathrm{HbA})^{*}$ & 0.56 \\
\hline Acanthocytosis & $y=-0.8+2.95(\mathrm{HbA}) *$ & 0.48 \\
\hline Spherocytosis & $y=-44.6+10.4(\mathrm{Hb}) *$ & 0.67 \\
\hline Schizocytosis & $y=12.9-1.1(\mathrm{Hb}) *$ & 0.38 \\
\hline
\end{tabular}

$\mathrm{Hb}, \mathrm{Hb}$ concentration; $\mathrm{HbA}$, adult $\mathrm{Hb}$ concentration; $*=P<0.01$.

\section{Discussion}

The neonatal anaemia of roan antelopes is associated with low and decreasing concentrations of fetal haemoglobins and the onset of adult $\mathrm{Hb}$ production (Fig. 3). The possibility that this scenario results from compromised intra-uterine $\mathrm{Hb}$ production is not excluded, but a number of studies suggest that the $\mathrm{Hb}$ "switching pattern" described above, indicates an imbalance between the conclusion of fetal $\mathrm{Hb}$ synthesis and the initiation of adult $\mathrm{Hb}$ synthesis, and that this pattern is normal in the roan antelope.

Numerous reports of neonatal anaemia, often in conjunction with anisocytosis, poikilocytosis and reticulocytosis, in various ruminant species, including those other than the Hippotragini, suggest that this picture represents a non-pathological occurrence (Karesh et al., 1986; Roeder et al., 1990).

Domestic goats, A-haplotype sheep (Ovis aries) and mouflon (Ovis musimon), shown to be closely related to roan antelopes (Hassanin and Douzery, 1999), display a perinatal Hb switching pattern in which the onset of adult $\mathrm{Hb}$ synthesis is delayed relative to the conclusion of fetal Hb synthesis (Huisman et al., 1969; Blunt and Huisman, 1975; Masala et al., 1991). These species, however, produce a third $\mathrm{Hb}, \mathrm{HbC}$, during this period and switch from adult $\mathrm{Hb}$ synthesis to that of $\mathrm{HbC}$ in response to adult-onset anaemia and erythropoeitin treatment. The fetal to adult $\mathrm{Hb}$ switching pattern of the roan antelope most closely resembles that of the mouflon (Fig. 5). 


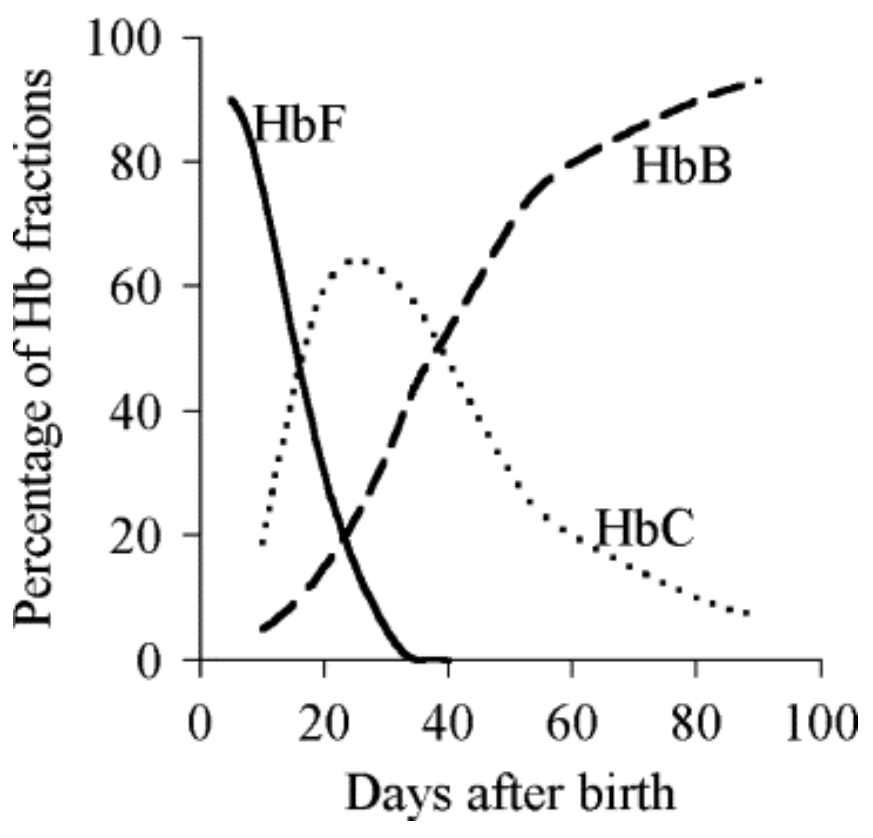

Fig. 5. Neonatal haemoglobin $(\mathrm{Hb})$ switching pattern of the mouflon (Reproduced from Masala et al., 1991). Haemoglobin B (HbB) is the adult $\mathrm{Hb}$ of the mouflon.

The peak in reticulocytosis in roan antelope calves 7 days after birth suggests a recent and acute drop in Hb concentration in these animals (Jain, 1993), as might be expected with the conclusion of fetal Hb synthesis (Fig. 5).

Accepting that the Hb switching pattern described above is non-pathological, extrapolation of these data provides for the perinatal switching pattern illustrated in Fig. 6. In this case, total $\mathrm{Hb}$ production during this period would be represented by the curve in Fig. 7 and an explanation is provided for the profound anaemia present during this time. Those members of the Caprini that produce $\mathrm{HbC}$ during the perinatal period, in contrast to the roan antelope, display a neonatal anaemia which is far milder. 


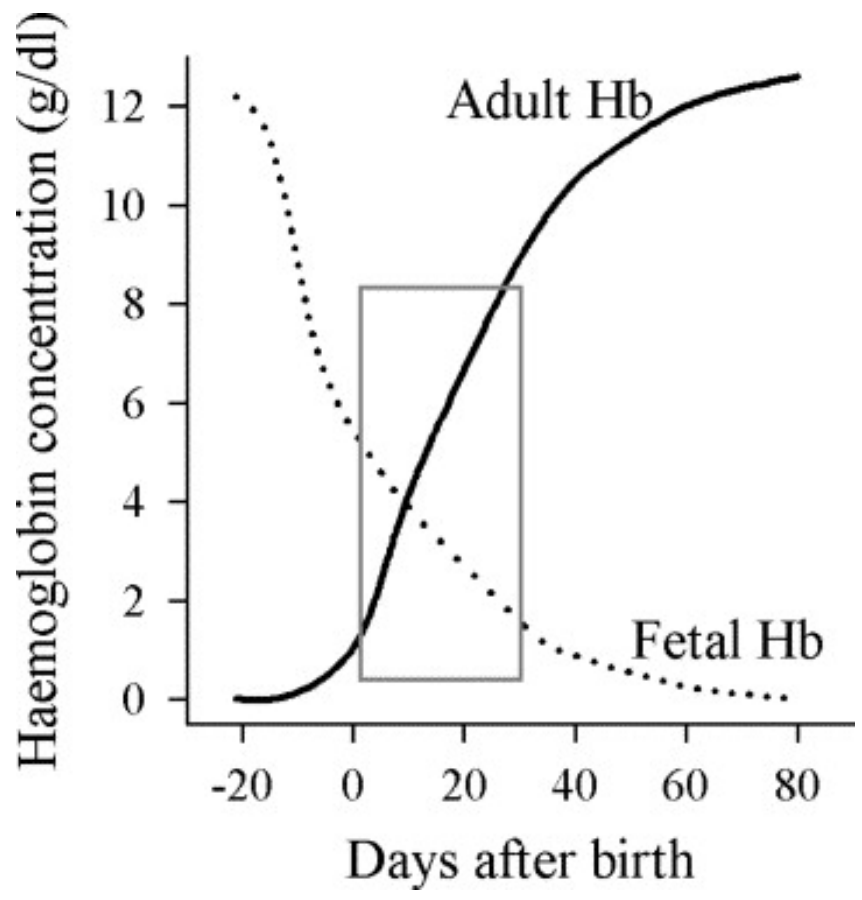

Fig. 6. Perinatal $\mathrm{Hb}$ switching pattern of the roan antelope, extrapolated from the neonatal Hb switching pattern (inside "box").

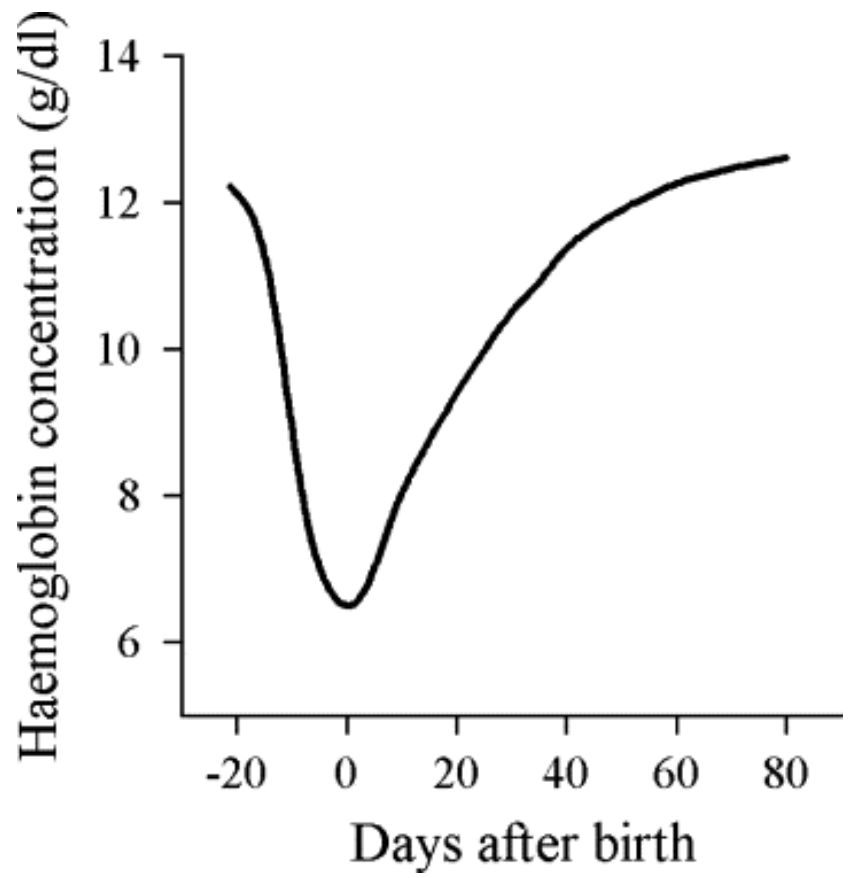

Fig. 7. Perinatal $\mathrm{Hb}$ production in the roan antelope, extrapolated from Fig. 6. 
The neonatal $\mathrm{Hb}$ switching pattern of the common ancestor of the goat and roan antelope cannot be predicted with certainty from current evidence. The $\beta^{\mathrm{C}}$-globin gene probably evolved about 12 million years ago (Li and Gojobori, 1983), while the divergence of the subfamily Antilopinae into distinct tribes is estimated to have occurred between 13.6 and 15.3 million years ago (Hassanin and Douzery, 1999). It seems probable, therefore, that $\mathrm{HbC}$ appeared in the goat and sheep lineage following divergence from the Hippotragus lineage and that the $\mathrm{Hb}$ switching pattern of the roan antelope may be indicative of that of the common ancestral ruminant.

It is believed, however, that the Caprini and Hippotragini belong to a single clade which probably diverged more recently than did other antelope tribes. This, and difficulties in accurately dating evolutionary events (Hassanin and Douzery, 1999), suggest that the possibility that these tribes diverged following the evolution of $\mathrm{HbC}$ cannot be excluded. The neonatal $\mathrm{Hb}$ switching patterns of goats, A-haplotype sheep and mouflon differ markedly and it is possible that the production of $\mathrm{HbC}$ has allowed the onset of adult $\mathrm{Hb}$ synthesis to drift forward to different degrees in the ontogeny of these species. If a common ancestral ruminant of the Caprini and Hippotragini produced $\mathrm{HbC}$ during the perinatal period, this may have allowed the delay in onset of adult $\mathrm{Hb}$ to evolve. $\mathrm{The} \mathrm{Hb}$ switching pattern of the roan antelope might then be explained as the result of the deletion or dysfunction of the $\beta^{\mathrm{C}}$-globin gene. Such a deletion is believed to have occurred in B-haplotype sheep (Garner and Lingrel, 1988).

Whichever evolutionary scenario proves to be correct, the drop and subsequent rise in $\mathrm{Hb}$ synthesis during the perinatal period provides for a possible explanation for the profound poikilocytosis, schizocytosis and reduced haematocrit observed in the roan antelope during this period. The predictable, progressive change in the numbers of various erythrocyte morphological types during the first 4 weeks after birth points to a progressive change in the underlying membrane pathology of these cells. More specifically, changes in the numbers of certain morphological cell types are related to increasing $\mathrm{Hb}$ concentrations and therefore, by extension, to increasing synthesis of adult ß-globin chains.

In $\beta$-thalassaemia, a human disease characterized by a hypochromic, poikilocytic anaemia, abnormalities in the production of adult $\beta$-globin chains of $\mathrm{Hb}$ result in a buildup of excess intracellular $\alpha$-globin chains. Excess globin chains have been shown to aggregate and adhere to erythrocyte membrane and membrane skeleton proteins, resulting in intramedullary cell death, cell shape alterations, increased fragility, and reduced lifespan (Rachmilewitz and Schrier, 2001). If the synthesis of $\beta$-globin is reduced in the neonatal roan antelope and that of $\alpha$-globin is not, a thalassaemic episode may prove to be the underlying pathology of the poikilocytic erythrocytes. As the production of adult $\beta$-globin increases over time, the $\alpha$-globin chain excess decreases, resulting in changes in erythrocyte membrane pathology. An imbalance between $\beta^{\mathrm{C}}$ - and $\alpha$-globin synthesis may also prove to be the cause of the $\mathrm{HbC}$-associated poikilocytosis of goats.

The consequence of a possible $\beta^{\mathrm{C}}$-thalassaemia in the roan antelope makes for interesting speculation. Haemoglobin $\mathrm{C}$ would not be produced in adult animals under anaemic 
conditions, but the mechanism for "switching off" adult Hb synthesis might still be functional. In effect, the onset of anaemia in the adult roan antelope might trigger a thalassaemic episode. This possibility is supported by the observation of poikilocytosis in an anaemic 18-month-old roan antelope (M. du Plessis, pers. com.).

Speculating on the adaptive advantage of neonatal anaemia, Steyl et al. (2003) suggested that it may enhance the "freezing" and hiding behaviour known to occur in calves of the Hippotragini (Skinner and Smithers, 1990). In addition, gestation length may be influenced by $\mathrm{Hb}$ switching. This switching is regulated by a "molecular clock" in that factors specific to fetal developmental stages are believed to control the sequential production of different haemoglobins (Baron, 1997). In the case of the roan antelope, decreasing $\mathrm{Hb}$ concentrations during the fetal/adult $\mathrm{Hb}$ switching period will therefore, at a specific gestational age, stimulate a fetal hypoxic stress response that may contribute to the initiation of partus (Liggins et al., 1973). By synchronizing gestation length, this mechanism would complement oestrus synchronization, shown to occur in the sable antelope (Hippotragus niger) (Thompson, 1995), resulting in synchronization of calving within a herd.

The possible link between the increased susceptibility to theileriosis and the anaemia of neonatal roan antelope was not specifically investigated in this study. However, it would seem unlikely that such anaemia is related to a toxicosis or nutritional deficiency. This suggests a direct relationship between the low $\mathrm{Hb}$ levels and the increased susceptibility to haemoprotozoal disease. Further investigation into the role of $\mathrm{Hb}$, and specifically $\mathrm{HbC}$ of members of the Caprini, in resistance to Theileria and other haemoprotozoa might prove rewarding.

\section{References}

Baron, 1997 M.H. Baron, Transcriptional control of globin gene switching during vertebrate development, Biochimica et Biophysica Acta 1351 (1997), pp. 51-72.

Bell, 1998 A. Bell, Morphologic evaluation of erythrocytes. In: E. Stiene-Martin, C.A. Lotspeich-Steininger and J.A. Koepke, Editors, Clinical Haematology; Principles, Procedures, Correlations, 2nd Edit., Lippencott-Raven Publishers, Philadelphia (1998), pp. 87-105.

Bessis, 1977 M. Bessis, Blood Smears Reinterpreted, Springer, Berlin (1977) pp. 50-101.

Blunt and Huisman, 1975 M.H. Blunt and T.H.J. Huisman, The haemoglobins of sheep. In: M.H. Blunt, Editor, The Blood of Sheep, Springer, Berlin (1975), pp. 155-184. 
Bush et al., 1976 M. Bush, U.S. Seal, E. Smith, M.D. Lewis and L.M. Bush, Neonatal anaemia and growth in sable antelope (Hippotragus niger), Erkrankungen der Zootiere. Verhandlungsbericht des XVIII. Internationalen Symposiums über die Erkrankungen der Zootiere, 1976, Innsbruck, Akademie-Verlag, Berlin (1976), pp. 361-379.

Garner and Lingrel, 1988 K.J. Garner and J.B. Lingrel, Structural organization of the Bglobin locus of B-haplotype sheep, Molecular Biology Evolution 5 (1988), pp. 134-140.

Hassanin and Douzery, 1999 A. Hassanin and E.J.P. Douzery, The tribal radiation of the family Bovidae (Artiodactyla) and the evolution of the mitochondrial cytochrome $b$ gene, Molecular Phylogenetics and Evolution 13 (1999), pp. 227-243.

Hawkey and Hart, 1984 C.M. Hawkey and M.G. Hart, Age-related changes in the blood count of the scimitar-horned oryx (Oryx tao), Journal of Zoo Animal Medicine 15 (1984), pp. 157-160.

Hawkey and Dennett, 1989 C.M. Hawkey and T.B. Dennett, Comparative Veterinary Haematology, Wolf Medical Publishing, Ipswich (1989) pp. 52,53.

Holman and Drew, 1964 H.H. Holman and S.M. Drew, The blood picture of the goat. II. Changes in erythrocytic shape, size and number associated with age, Research in Veterinary Science 5 (1964), pp. 274-285.

Huisman et al., 1969 T.H.J. Huisman, J.P. Lewis, M.H. Blunt, H.R. Adams, A. Miller, A.M. Dozy and E.M. Boyd, Hemoglobin C in newborn sheep and goats: a possible explanation for its function and biosynthesis, Paediatric Research 3 (1969), pp. 189-198.

Jain et al., 1980 N.C. Jain, C.S. Kono, A. Myers and K. Bottomly, Fusiform erythrocytes resembling sickle cells in Angora goats: observations on osmotic and mechanical fragilities and reversal of cell shape during anaemia, Research in Veterinary Science $\mathbf{2 8}$ (1980), pp. 25-35.

Jain, 1986 N.C. Jain, Schalm's Veterinary Haematology, 4th Edit., Lea \& Febiger, Philadelphia (1986) pp. 527-62.

Jain, 1993 N.C. Jain, Essentials of Veterinary Hematology, Lea \& Febiger, Philadelphia (1993) pp. 32.

Karesh et al., 1986 W.B. Karesh, D.L. Janssen and J.E. Oosterhuis, Neonatal hematology of selected species of Cervidae and Bovidae, Journal of Zoo Animal Medicine 17 (1986), pp. 138-146.

Li and Gojobori, 1983 W.-H. Li and T. Gojobori, Rapid evolution of goat and sheep globin genes following gene duplication, Molecular and Biological Evolution 1 (1983), pp. 94-108. 
Liggins et al., 1973 G.C. Liggins, R.J. Fairclough, S.A. Grieves, J.Z. Kendall and B.S. Knox, The mechanism of initiation of parturition in the ewe, Recent Progress in Hormone Research 29 (1973), pp. 111-159.

Masala et al., 1991 B. Masala, L. Manca, E. Cocco, S. Ledda and S. Naitana, Kinetics of the ontogenic and reversible hemoglobin switching in the mouflon (Ovis musimon) and sheep x mouflon hybrid, Comparative Biochemistry Physiology A 100 (1991), pp. 675680 .

Rachmilewitz and Schrier, 2001 E. Rachmilewitz and S.L. Schrier, Pathophysiology of $\beta$ thalassemia. In: M.H. Steinberg, B.G. Forget, D.R. Higgs and R.L. Nagel, Editors, Disorders of Hemoglobin, Cambridge University Press, Cambridge (2001), pp. 233-251.

Roeder et al., 1990 B.L. Roeder, G.C. Loop and J.E. Johnson, Comparative hematologic and serum chemistry values for neonatal, juvenile, and adult blue duiker (Cephalophus monticola bicolor), Journal of Zoo and Wildlife Medicine 21 (1990), pp. 433-446.

Skinner and Smithers, 1990 J.D. Skinner and R.H.N. Smithers, The Mammals of the Southern African Subregion, University of Pretoria, Pretoria (1990) pp. 673-80.

Steyl et al., 2003 J. Steyl, J. Lawrence, L. Prozesky and H. Stoltsz, Theileriosis in Roan Antelope, Hooo-Hooo (Newsletter of the Wildlife Group of the South African Veterinary Association) 7 (2003), pp. 4-9.

Swirsky and Bain, 2001 D. Swirsky and B.J. Bain, Erythrocyte and leucocyte cytochemistry—leukaemia classification. In: S.M. Lewis, I. Bates and B.J. Bain, Editors, Practical Haematology, 9th Edit., Harcourt Publishers, London (2001), pp. 269-295.

Thompson, 1995 K.V. Thompson, Flehmen and birth synchrony among female sable antelope, Hippotragus niger, Animal Behaviour 50 (1995), pp. 475-484. 